\title{
Temperature effects on life history traits of the corn leaf aphid, Rhopalosiphum maidis (Homoptera: Aphididae) on corn in Taiwan
}

\author{
Mei Hwa Kuo, ${ }^{1}$ Ming Chih Chiu ${ }^{1}$ and Jen Jiun Perng ${ }^{2, *}$ \\ ${ }^{1}$ Department of Entomology, National Chung Hsing University; Taichung 402, Taiwan \\ ${ }^{2}$ Institute of Life Science, National Taitung University; Taitung 950, Taiwan \\ (Received 1 August 2005; Accepted 9 November 2005)
}

\begin{abstract}
The effects of temperature on the life history traits of Rhopalosiphum maidis (Fitch) were determined at 6, 10, 15, 20, 25,30 , and $35 \pm 1{ }^{\circ} \mathrm{C}$ on corn leaves, Zea mays (L.). At $35^{\circ} \mathrm{C}$, only a few nymphs survived and completed development, but all failed to reproduce. Total immature stages from birth to adult decreased as temperature increased from $51.7 \mathrm{~d}$ at $6^{\circ} \mathrm{C}$ to $5.2 \mathrm{~d}$ at $30^{\circ} \mathrm{C}$, but became $8.0 \mathrm{~d}$ at $35^{\circ} \mathrm{C}$. Overall immature development required 119.05 degree-days above $4.44^{\circ} \mathrm{C}$. Adult longevity was as high as $26.7 \mathrm{~d}$ at $15^{\circ} \mathrm{C}$, but significantly declined at 30 and $35^{\circ} \mathrm{C}$. The average adult fecundity was as high as 45 offspring at 15 and $20^{\circ} \mathrm{C}$, but dropped to 1.8 at $6^{\circ} \mathrm{C}$ and 8.6 at $30^{\circ} \mathrm{C}$. In general, as temperatures increased, age-specific survivorship $\left(l_{x}\right)$ declined more quickly, but age-specific fecundity $\left(m_{x}\right)$ peaked earlier. At $25^{\circ} \mathrm{C}$, the age-specific net maternity $\left(v_{x}=l_{x} m_{x}\right)$ was the highest in the early reproductive period, resulting in the highest intrinsic rates of increase $\left(r_{m}=0.329\right)$. At $20-30^{\circ} \mathrm{C}$, the values of $r_{m}$ were significantly higher than those at lower temperatures. The results indicate that corn leaf aphids probably are better adapted in population growth to a wider range of high temperatures in warm regions.
\end{abstract}

Key words: Development; fecundity; survivorship; degree-days; population growth

\section{INTRODUCTION}

Corn leaf aphid (Rhopalosiphum maidis Fitch), a polyphagous species of aphid known to attack more than 30 genera of the Gramineae and most cereal crops, was originally an Asiatic species, but is now distributed worldwide in the tropics, subtropics, and warmer temperate regions (Blackman and Eastop, 2000). Severe infestation of this aphid can cause serious yield losses of cereals through feeding damage, tassel cover by honeydew (Everly, 1960; Foott and Timmins, 1973; Kieckhefer and Kantack, 1980, 1986; Bing et al., 1991), and viral infection (Blackman and Eastop, 2000).

The corn leaf aphid may be the most important aphid pest of cereals in tropical and warm temperature climates (Blackman and Eastop, 2000). In Egypt, it feeds on many graminaceous weeds and cereals and is a serious pest of corn crops (ElIbrashy et al., 1972). Although corn leaf aphids are not tolerant of cold temperatures, they migrate northward in the spring from southern overwintering sites (Wildermuth and Walter, 1932; Carter, 1957), and have become a common aphid pest of grains (Adams and Drew, 1964) in North America. They are active and excrete honeydew at about $23.9^{\circ} \mathrm{C}$ but do not move at $15.6^{\circ} \mathrm{C}$, and they can withstand temperatures to $49.7^{\circ} \mathrm{C}$ in a greenhouse (Carter, 1957).

The effects of six constant temperatures $(10,15$, $20,25,30$, and $35^{\circ} \mathrm{C}$ ) on the development and some biotic potentials of corn leaf aphids on barley were studied in Egypt (El-Ibrashy et al., 1972). The effects of six constant temperatures $(11,15,19,23$, 26 , and $29^{\circ} \mathrm{C}$ ) and three fluctuating temperatures (average: 18,22 , and $29^{\circ} \mathrm{C}$ ) on the development of corn leaf aphids on barley were studied in the US, but only the effects of the three fluctuating temperatures on population growth statistics were reported (Elliott et al., 1988). Related studies have never been reported in Asia. Furthermore, variations in life history traits reflecting adaptations to

* To whom correspondence should be addressed at: E-mail: jjperng@nttu.edu.tw DOI: $10.1303 /$ aez.2006.171 
local climatic conditions or different host plants may occur among different insect populations (Lamb, 1992; Tang et al., 1999; Weber et al., 1999). Therefore, we studied the effects of seven constant temperatures $(6,10,15,20,25,30$, and $35^{\circ} \mathrm{C}$ ) on the life history traits, including developmental, longevity, fecundity and population growth statistics of corn leaf aphids reared on corn leaves in subtropical Taiwan, northeastern Asia, to better understand the variations in life history traits among different geographically separated populations.

\section{MATERIALS AND METHODS}

Insect culture. In April-September 2001, corn leaf aphids were collected in a cornfield of the Taiwan Agricultural Research Institute, Taichung, west central Taiwan. The stock colony was reared on the Tainung 1 strain of corn, Zea mays L., in a greenhouse. Aphids were subsequently reared on corn leaves in plastic Petri dishes $(9 \mathrm{~cm}$ in diameter, $1 \mathrm{~cm}$ high) for a number of generations in a growth chamber at $25^{\circ} \mathrm{C}$ and a photoperiod of $12 \mathrm{~L}: 12 \mathrm{D}$. The fifth corn leaf $(6 \times 6 \mathrm{~cm})$ from the top of corn seedlings 1-2 mo old were detached and placed in a Petri dish with a moist cotton ball on one side of the leaf margin. The leaves were cleaned and checked to be free of aphids. To prevent nutritional deficiencies, every $2-3 \mathrm{~d}$ the leaves were replaced with fresh ones.

Life table experiment. Approximately 350 adult aphids from the stock colonies were transferred to 70 Petri dishes with corn leaves in a growth chamber at $25^{\circ} \mathrm{C}$ for a $4 \mathrm{~h}$ reproduction period. Then, using a fine-tipped paintbrush, each newborn nymph was carefully transferred to a $6 \mathrm{~cm}$ corn leaf in a Petri dish with a wet cotton ball. In the experiment, a cohort of 60-90 nymphs was reared at each of seven constant temperatures $(6$, $10,15,20,25,30$, and $\left.35 \pm 1{ }^{\circ} \mathrm{C}\right), 75-85 \% \mathrm{RH}$, and a photoperiod of $12 \mathrm{~L}: 12 \mathrm{D}$. Thereafter, each aphid was examined daily to monitor its development, fecundity, and survivorship. During the reproductive period, newborn nymphs were counted daily and then removed. Corn leaves were replaced at least every $3 \mathrm{~d}$ throughout the study period.

Data analyses and statistics. Differences in adult longevity and fecundity at various constant temperatures were tested for significance by analy- sis of variance (ANOVA) using the general linear model (PROC GLM, SAS Institute, 1989). Means were separated by Tukey's honest significant difference test after a significant $F$-test at $p=0.05$.

The linear relationship between development rate $(Y(X))$ and temperature $(X)$ (from 6 to $25^{\circ} \mathrm{C}$ ) was fit to the degree-days model,

$$
Y(X)=a+b X,
$$

where $a$ is the intercept, and $b$ is the slope. The lower developmental threshold temperatures $\left(X_{L}\right)$ were estimated from $X_{L}=-a / b$. The development times in degree-days (DD) of immature stages were calculated as $1 / b$.

A 3rd-degree model was used to describe the nonlinear relationship between nymphal developmental rates $(Y)$ and temperatures $(X)$ within $6-35^{\circ} \mathrm{C}$ :

$$
Y(X)=a_{0}+a_{1} X+a_{2} X^{2}+a_{3} X^{3} ;
$$

where $a_{0}, a_{1}, a_{2}$, and $a_{3}$ are empirical constants (Harcourt and Yee, 1982).

Population growth statistics, including the intrinsic rate of increase $\left(r_{m}\right)$, net reproductive rate $\left(R_{o}\right)$, and mean generation time (GT) were calculated for populations at different temperatures using the computer program provided by Chi (1997). Differences in the life table statistics among temperatures were also analyzed using Tukey's honest significant difference tests based on jackknife estimates of variance for these statistics (Meyer et al., 1986).

\section{RESULTS}

\section{Nymphal development}

For each instar, the developmental times of $R$. maidis decreased with increasing temperature up to $30^{\circ} \mathrm{C}$ (Table 1). The developmental rates of all instars and total immature stages from birth to adult increased linearly with temperatures from 6 to $25^{\circ} \mathrm{C}$ then reached to the maximums at $30^{\circ} \mathrm{C}$, but obviously decreased at $35^{\circ} \mathrm{C}$ (Fig. 1). Although the increasing rates of all the developmental rates at $30^{\circ} \mathrm{C}$ slightly slowed down, they were still the maximum development rates (Fig. 1), i.e. the shortest development times (Table 1), in comparison with those at other temperatures used in this study, therefore $30^{\circ} \mathrm{C}$ was the temperature most close to the optimal temperature for immature development. At $35^{\circ} \mathrm{C}$, only a few nymphs survived and 
Table 1. Developmental times of Rhopalosiphum maidis nymphal stages at various temperatures

\begin{tabular}{|c|c|c|c|c|c|c|c|c|c|c|}
\hline \multirow{2}{*}{$\begin{array}{c}\text { Temp. } \\
\left({ }^{\circ} \mathrm{C}\right)\end{array}$} & \multicolumn{9}{|c|}{ Developmental time $(\mathrm{d} \pm \mathrm{SE})$} & \multirow[b]{2}{*}{ Total } \\
\hline & $n$ & Instar 1 & $n$ & Instar 2 & $n$ & Instar 3 & $n$ & Instar 4 & $n$ & \\
\hline 6 & 62 & $11.0 \pm 1.2$ & 40 & $13.5 \pm 0.9$ & 22 & $14.3 \pm 1.3$ & 9 & $13.9 \pm 1.6$ & 9 & $51.7 \pm 2.8$ \\
\hline 10 & 68 & $5.9 \pm 0.2$ & 62 & $5.9 \pm 0.3$ & 56 & $6.0 \pm 0.3$ & 48 & $6.5 \pm 0.3$ & 48 & $24.0 \pm 0.5$ \\
\hline 15 & 69 & $3.5 \pm 0.1$ & 62 & $3.4 \pm 0.2$ & 61 & $3.3 \pm 0.2$ & 59 & $2.9 \pm 0.1$ & 59 & $12.9 \pm 0.3$ \\
\hline 20 & 79 & $2.2 \pm 0.1$ & 71 & $2.0 \pm 0.1$ & 65 & $1.8 \pm 0.1$ & 64 & $1.6 \pm 0.1$ & 64 & $7.6 \pm 0.1$ \\
\hline 25 & 59 & $1.5 \pm 0.1$ & 58 & $1.5 \pm 0.1$ & 57 & $1.4 \pm 0.1$ & 57 & $1.4 \pm 0.1$ & 57 & $5.7 \pm 0.2$ \\
\hline 30 & 82 & $1.4 \pm 0.1$ & 74 & $1.4 \pm 0.1$ & 71 & $1.2 \pm 0.0$ & 68 & $1.2 \pm 0.1$ & 68 & $5.2 \pm 0.1$ \\
\hline 35 & 58 & $2.3 \pm 0.2$ & 30 & $2.4 \pm 0.3$ & 9 & $2.3 \pm 0.4$ & 2 & $3.5 \pm 0.5$ & 2 & $8.0 \pm 1.0$ \\
\hline
\end{tabular}

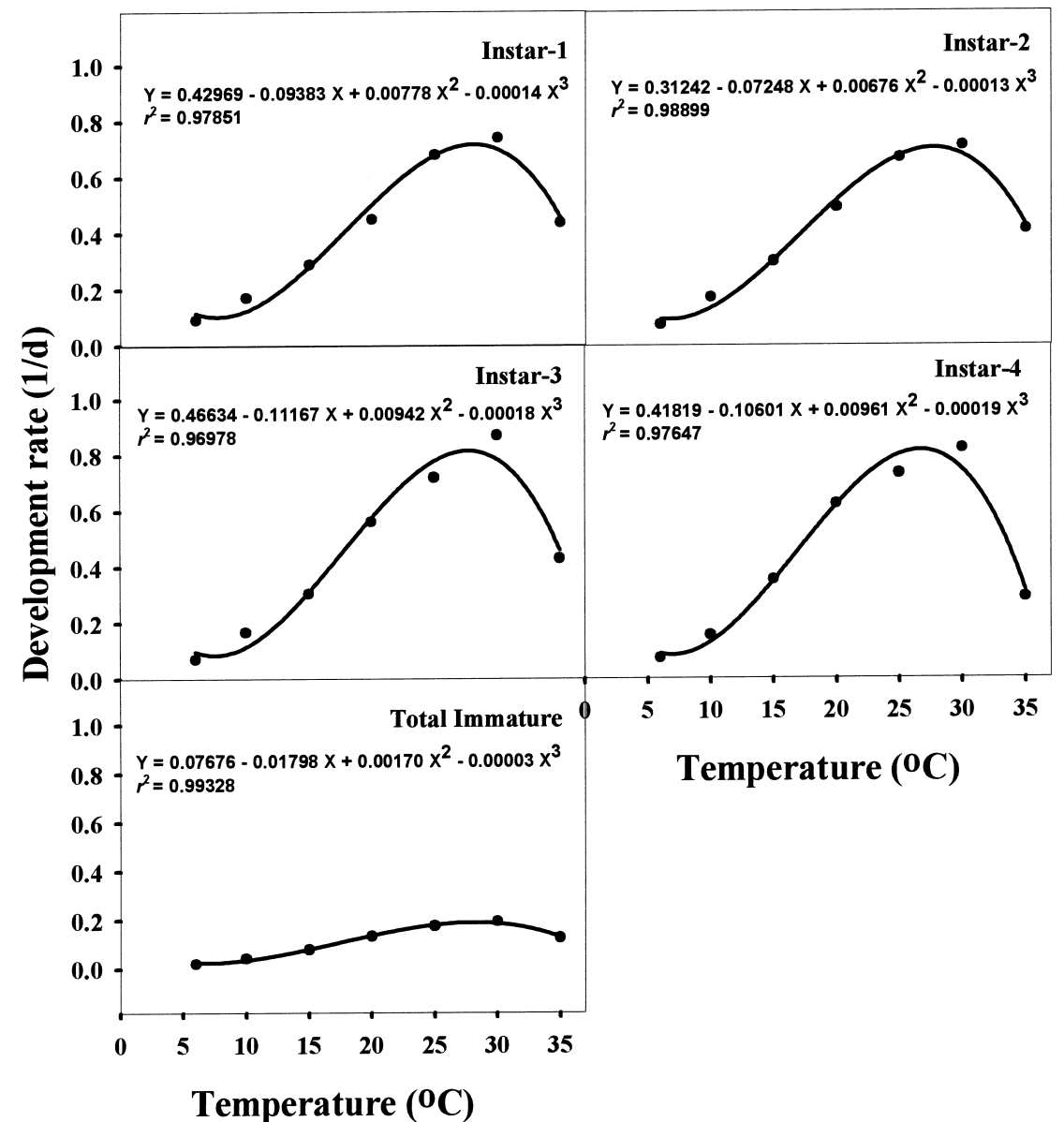

Fig. 1. Observed development rates for immature stages of Rhopalosiphum maidis on corn leaves within the range of 6-35 ${ }^{\circ}$, and curves fit to these data by a nonlinear regression.

completed development, but none of them succeeded in reproducing.

The results of linear regression analysis for nymphal developmental rates and temperatures within the range of $6-25^{\circ} \mathrm{C}$ are shown in Table 2 . The estimated lower developmental thresholds were $4.12,4.57,5.02,5.04$, and $4.44^{\circ} \mathrm{C}$ from the first through fourth instars and total immature stage, respectively (Table 2). Estimates of developmental times in degree-days decreased from 33.15 DD for first instars to 25.96 DD for fourth instars. Total immature development required 119.05 DD above $4.44^{\circ} \mathrm{C}$ (Table 2). The 3rd-degree model fit the data well, and adequately predicted 
Table 2. Linear regression analysis for developmental rates of Rhopalosiphum maidis immature stages within the temperature range of $6-25^{\circ} \mathrm{C}$

\begin{tabular}{clcccc}
\hline Instar & Regression equation & $r^{2}$ & $p$ value & $\begin{array}{c}\text { Developmental } \\
\text { time in DD }\end{array}$ & $\begin{array}{c}\text { Low developmental } \\
\text { threshold }\left({ }^{\circ} \mathrm{C}\right)\end{array}$ \\
\hline 1 & $Y=-0.124+0.030 X$ & 0.976 & 0.0016 & 33.15 & 4.12 \\
2 & $Y=-0.147+0.032 X$ & 0.981 & 0.0008 & 31.19 & 4.57 \\
3 & $Y=-0.178+0.035 X$ & 0.978 & 0.0014 & 28.19 & 5.02 \\
4 & $Y=-0.194+0.039 X$ & 0.961 & 0.0033 & 25.96 & 5.04 \\
Total & $Y=-0.037+0.008 X$ & 0.989 & 0.0005 & 119.05 & 4.44 \\
\hline
\end{tabular}

DD, degree-days; $X$, temperature $\left({ }^{\circ} \mathrm{C}\right) ; Y$, developmental rate $(1 / \mathrm{d})$.

Table 3. Longevity and fecundity (mean $\pm \mathrm{SE}$ ) of Rhopalosiphum maidis adults at various temperatures

\begin{tabular}{rrcc}
\hline $\begin{array}{c}\text { Temp. } \\
\left({ }^{\circ} \mathrm{C}\right)\end{array}$ & $n$ & $\begin{array}{c}\text { Longevity } \\
(\mathrm{d})\end{array}$ & $\begin{array}{c}\text { Fecundity } \\
\text { (offspring per mother) }\end{array}$ \\
\hline 6 & 9 & $14.8 \pm 3.9 \mathrm{bcd}$ & $1.8 \pm 0.8 \mathrm{~d}$ \\
10 & 48 & $20.0 \pm 2.2 \mathrm{abc}$ & $15.8 \pm 2.4 \mathrm{~cd}$ \\
15 & 59 & $26.7 \pm 1.9 \mathrm{a}$ & $43.7 \pm 3.0 \mathrm{a}$ \\
20 & 64 & $23.1 \pm 1.5 \mathrm{ab}$ & $47.0 \pm 2.6 \mathrm{a}$ \\
25 & 57 & $12.0 \pm 0.9 \mathrm{~cd}$ & $34.2 \pm 2.7 \mathrm{ab}$ \\
30 & 68 & $8.6 \pm 0.6 \mathrm{~d}$ & $24.9 \pm 2.2 \mathrm{bc}$ \\
35 & 2 & $4.0 \pm 0.0^{*}$ & $0.0 \pm 0.0^{*}$ \\
\hline
\end{tabular}

Within a column, means with the same letter do not significantly differ $(p>0.05)$ according to Tukey's honest significant difference test.

* Since only two nymphs survived and developed to the adult stage out of the initial cohort $(n=58)$ at $35^{\circ} \mathrm{C}$, we did not use this set of data for statistical analysis.

the development rates (Fig. 1).

\section{Adult longevity and fecundity}

At $35^{\circ} \mathrm{C}$, since only two nymphs survived and completed development out of the initial cohort $(n=58)$, but all failed in reproducing (Table 3$)$, we did not use the data of adult longevity and fecundity at $35^{\circ} \mathrm{C}$ for statistical analysis. Within $6-30^{\circ} \mathrm{C}$, adult longevity and fecundity were both significantly affected by temperature $(F=21.73$; d.f. $=5$, 299; $p<0.0001$ and $F=24.03$; d.f. $=5,299 ; p<$ 0.0001 , respectively). Adult longevity was as high as $26.7 \mathrm{~d}$ at $15^{\circ} \mathrm{C}$, but significantly declined at 30 and $35^{\circ} \mathrm{C}$ (Table 3 ). The highest values of adult fecundity were about 45 offspring per female, both at 15 and $20^{\circ} \mathrm{C}$. Adult fecundity was also adversely affected by both higher and lower temperatures. Corn leaf aphids almost or completely failed to reproduce at 6 and $35^{\circ} \mathrm{C}$, respectively (Table 3 ).

\section{Age-specific survivorship and fecundity}

The age-specific survivorship $\left(l_{x}\right)$ curves decreased more rapidly and even more sharply as temperature increased from 6 to $35^{\circ} \mathrm{C}$ (Fig. 2). At $6^{\circ} \mathrm{C}, 50 \%$ of mortality occurred on the 38 th day, and all aphids died on the 100th day. At $35^{\circ} \mathrm{C}$, the $50 \%$ of mortality occurred on the 7 th day, and all aphids died on the 14th day.

In general, the times needed for first reproduction decreased with increasing temperatures (Fig. 2 ). Most of the age-specific fecundity $\left(m_{x}\right)$ curves peaked soon after the onset of reproduction. Curves of $m_{x}$ peaked at the similar levels at 20, 25, and $30^{\circ} \mathrm{C}$. However, reproduction was strictly limited at $6^{\circ} \mathrm{C}$, and aphids failed to reproduce at $35^{\circ} \mathrm{C}$.

Because all $l_{x}$ curves declined with age during the entire reproductive stage at each temperature, the age-specific net maternity $\left(v_{x}=l_{x} m_{x}\right)$ curve distinctly departed from that of age-specific fecundity $\left(m_{x}\right)$ (Fig. 2). At $25^{\circ} \mathrm{C}$, because both $l_{x}$ and $m_{x}$ reached relatively higher levels than those at other temperatures, especially during the early reproductive stage, the age-specific net maternity curve had the highest level.

\section{Population growth statistics}

Values of the intrinsic rate of increase $\left(r_{m}\right)$ differed significantly among the six temperatures $(F=273.86$; d.f. $=5,413 ; p<0.0001)$. Values of $r_{m}$ rose as the temperature increased from 6 to $25^{\circ} \mathrm{C}$ (Table 4). Temperature significantly affected the respective net reproductive rates and mean generation times $(F=38.23$; d.f. $=5,413 ; p<0.0001$ and $F=96.06 ;$ d.f. $=5,413 ; p<0.0001$, respectively). The population reared at $20^{\circ} \mathrm{C}$ had the highest net reproductive rate $\left(R_{o}=38.0\right.$ offspring per female), and that at a low temperature $\left(6^{\circ} \mathrm{C}\right)$ had a small $R_{o}$ 


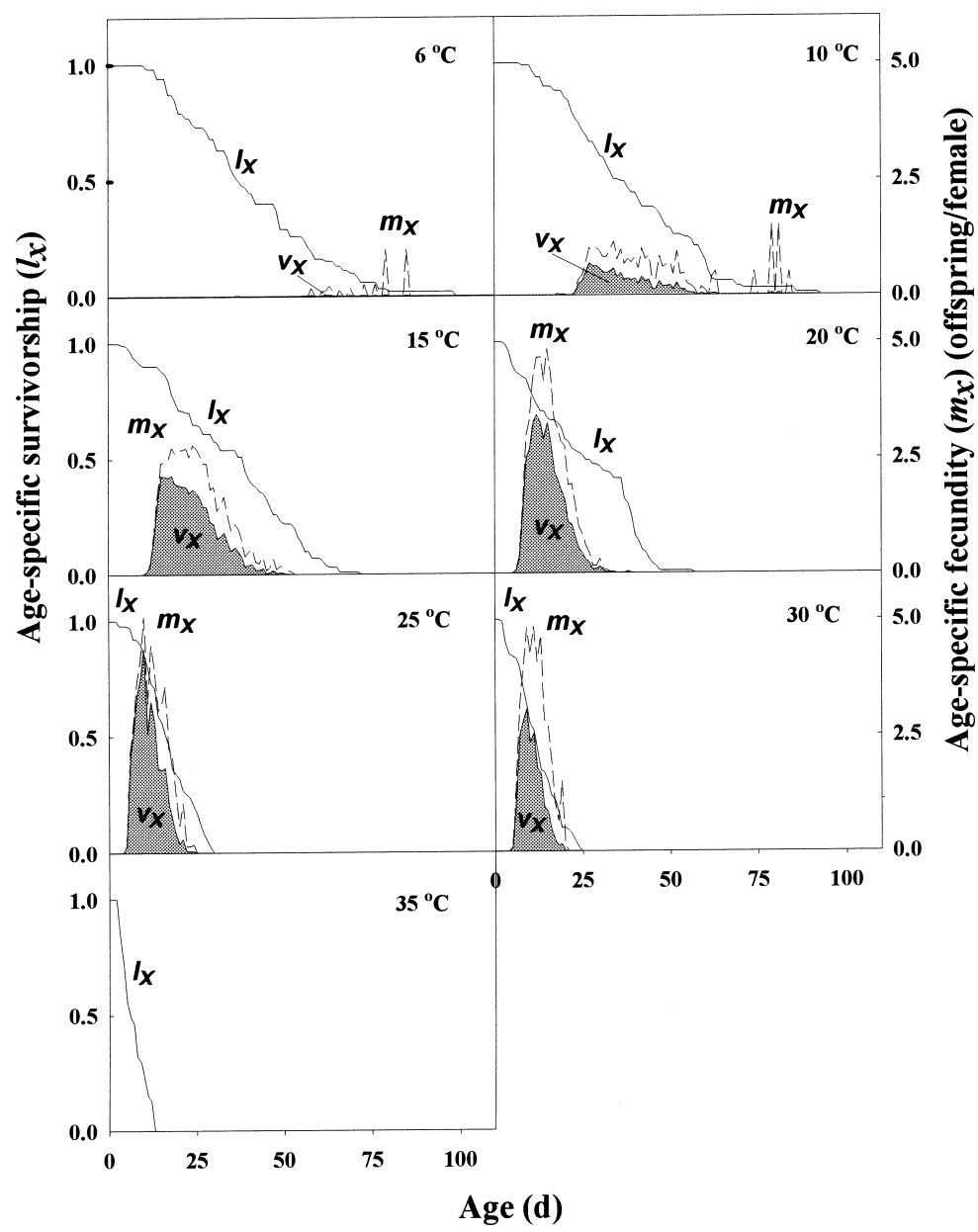

Fig. 2. Age-specific survivorship $\left(l_{x}\right)$, age-specific fecundity $\left(m_{x}\right)$, and net maternity value $\left(v_{x}=l_{x} m_{x}\right)$ of Rhopalosiphum maidis on corn leaves at various constant temperatures.

Table 4. Population growth statistics (mean $\pm \mathrm{SE}$ ) of Rhopalosiphum maidis at various temperatures

\begin{tabular}{rrrrr}
\hline $\begin{array}{c}\text { Temp. } \\
\left({ }^{\circ} \mathrm{C}\right)\end{array}$ & $n$ & $r_{m}$ & $R_{o}$ & $G T$ \\
\hline 6 & 62 & $-0.020 \pm 0.011 \mathrm{e}$ & $0.3 \pm 0.1 \mathrm{c}$ & $67.8 \pm 6.1 \mathrm{a}$ \\
10 & 68 & $0.069 \pm 0.005 \mathrm{~d}$ & $11.2 \pm 1.9 \mathrm{~b}$ & $35.0 \pm 0.7 \mathrm{~b}$ \\
15 & 69 & $0.171 \pm 0.010 \mathrm{c}$ & $37.4 \pm 3.2 \mathrm{a}$ & $21.2 \pm 0.4 \mathrm{c}$ \\
20 & 79 & $0.264 \pm 0.007 \mathrm{~b}$ & $38.0 \pm 3.0 \mathrm{a}$ & $13.8 \pm 0.2 \mathrm{~cd}$ \\
25 & 59 & $0.329 \pm 0.010 \mathrm{a}$ & $33.1 \pm 2.7 \mathrm{a}$ & $10.6 \pm 0.2 \mathrm{~d}$ \\
30 & 82 & $0.295 \pm 0.009 \mathrm{~b}$ & $20.6 \pm 2.1 \mathrm{~b}$ & $10.3 \pm 0.2 \mathrm{~d}$ \\
\hline
\end{tabular}

$n$, sample size; $r_{m}$, intrinsic rate of increase (nymphs per mother per day); $G T$, generation time (d); $R_{o}$, net reproductive rate (nymphs per mother).

Within a column, means with the same letter do not significantly differ $(p>0.05)$ according to Tukey's honest significant difference test.
(0.3 offspring per female). The mean generation time $(G T)$ decreased from 67.8 to $10.3 \mathrm{~d}$ as the temperature increased from 6 to $30^{\circ} \mathrm{C}$.

\section{DISCUSSION}

Durations of developmental times of various nymphal instars over the range of higher constant temperatures $\left(20-30^{\circ} \mathrm{C}\right)$ for apterous corn leaf aphids examined in this study were very similar to those reared on $5 \mathrm{~d}$-old barley plants studied in Egypt (El-Ibrashy et al., 1972) and those reared on seedling barley leaves studied in the US (Elliott et al., 1988). However, variations in developmental times between these studies increased over the range of lower temperatures $\left(10-15^{\circ} \mathrm{C}\right)$. The consistent developmental times of different geographically separated populations at high temperatures shows that their development seems to be more sta- 
bly adapted to warm climates.

A typical linear relationship between temperature and development rate in a moderate temperature range (ca. $10-25^{\circ} \mathrm{C}$ ) also occurred for immature stages of apterous corn leaf aphids reared on different host plants in another study (Elliott et al., 1988) and ours. The estimated low developmental thresholds of all immature stages reported by Elliott et al. (1988) and our study similarly occurred within a narrow range of temperatures. However, values of the low developmental thresholds $\left(4.12-5.04^{\circ} \mathrm{C}\right)$ on corn leaves in our study were consistently lower than those $\left(5.9-6.4^{\circ} \mathrm{C}\right)$ on seedling barley leaves reported by Elliott et al. (1988). In addition, for the total immature stage from birth to adult, the estimated low developmental threshold $\left(4.44^{\circ} \mathrm{C}\right)$ and the shortest developmental time at $30^{\circ} \mathrm{C}$ (around the optimal temperature) both obviously differed from 6.1 and $26^{\circ} \mathrm{C}$ on seedling barley leaves (Elliott et al., 1988), respectively. This means that corn leaf aphids have a wider temperature range for immature development on corn leaves than on barley leaves. However, the degree-day requirement for total immature development (119.05 DD) estimated by our study was higher than the $99.1 \mathrm{DD}$ estimated by Elliott et al. (1988). Overall, developmental variations for geographically separated populations of corn leaf aphids indicate a possibility of different adaptations of the aphids to different local climates (Lamb, 1992; Tang et al., 1999) or a combination effect of temperature, especially low temperatures, and host plants on the aphids (Nava-Camberos et al., 2001).

Adult longevity of corn leaf aphids was influenced by both temperature (Table 3) and age (Fig. 2). The values of adult longevity dramatically declined as temperatures increased to 30 and $35^{\circ} \mathrm{C}$. For higher temperatures, the age-specific survival curves dropped more sharply and quickly when temperatures increased from 20 to $35^{\circ} \mathrm{C}$. The deleterious effect of high temperatures on survivorship is very common in various aphids (Asin and Pons, 2001; Morgan et al., 2001; Wang and Tsai, 2001). In contrast, relatively lower temperatures (10$15^{\circ} \mathrm{C}$ ) show less adverse effects on the survival and longevity, similar to some other aphids (Asin and Pons, 2001; Wang and Tsai, 2001).

In this study, the developmental rates, intrinsic rate of increased, net reproductive rates, and recip- rocal of generation times increased as temperature increased, but they reached the highest values at respective optimal temperatures and then decreased as temperature increased. Values of $r_{m}$, which reflect the overall effects of temperature on development, reproduction, and survival of a population, increased as temperature increased from 6 to $25^{\circ} \mathrm{C}$, consistent with the trend of the developmental rate. However, $r_{m}$ decreased at $30^{\circ} \mathrm{C}$ as the net reproductive rate largely decreased, while the developmental rate still increased. Therefore, the value of $r_{m}$ at $30^{\circ} \mathrm{C}$ was significantly lower than that at $25^{\circ} \mathrm{C}$. Consequently, in our study, the optimum temperature for the highest population growth potential of the corn leaf aphid occurred at around $25^{\circ} \mathrm{C}$. The maximum $r_{m}$ of the corn leaf aphid was 0.329 at $25^{\circ} \mathrm{C}$, in comparison with the performances of three other corn aphids reported by Asin and Pons (2001), which was higher than the 0.30 at $25^{\circ} \mathrm{C}$ for Sitobion avenae (F.) and 0.24 at $22^{\circ} \mathrm{C}$ for Metopolophium dirhodum (Walker), but it is much lower than the 0.52 at $27.5^{\circ} \mathrm{C}$ for Rhopalosiphum padi (L.). However, at $30^{\circ} \mathrm{C}$, the value of $r_{m}$ in our study was still as high as 0.295 , which was much higher than the 0.05 for $R$. padi. Both $S$. avenae and $M$. dirhodum failed to survive at this temperature. Hence, the results indicate that corn leaf aphids probably are better adapted in population growth to a wider range of high temperatures in warm regions, similar to that reported in a previous study (El-Ibrashy et al., 1972). In contrast, the low or negative population growth at low temperatures indicates that it is difficult or impossible for corn leaf aphids to establish a population during the cold season. Overall, these results are consistent with earlier reports that corn leaf aphids may cause serious yield losses of cereals in tropical climates (Blackman and Eastop, 2000), and can achieve high density levels of northerly migrating populations during the warm season in North America including Canada (Wildermuth and Walter, 1932; Carter, 1957). In addition, since corn leaf aphids have short developmental times to maturation (about 7-8d) and high lifetime fecundity (about 50 nymphs per wingless female) on some grasses at $21.1^{\circ} \mathrm{C}$ (Adams and Drew, 1964) similar to that on corn in this study and on barely (Elliott et al., 1988), this conforms with the report that widely distributed grasses are good alternative host plants for the maintenance of aphid populations (Weibull, 
1993; Perng, 2002).

\section{ACKNOWLEDGEMENTS}

The authors are grateful to Mr. Dan Chamberlin for reviewing the manuscript. This study was partly supported by the $\mathrm{Bu}-$ reau of Animal and Plant Health Inspection and Quarantine Council of Agriculture of Taiwan, project 94AS-13.3.1-BQB2.

\section{REFERENCES}

Adams, J. B. and M. E. Drew (1964) Grain aphids in Brunswick. II. Comparative development in the greenhouse of three aphid species on four kinds of grasses. Can. J. Zool. 42: 741-744.

Asin, L. and X. Pons (2001) Effect of high temperature on the growth and reproduction of corn aphids (Homoptera: Aphididae) and implications for their population dynamics on the northeastern Iberian peninsula. Environ. Entomol. 30: 1127-1134.

Bing, J. W., W. D. Guthrie, F. F. Dicke and J. J. Obrycki (1991) Seedling stage feeding by corn leaf aphid (Homoptera: Aphididae): influence on plant development in maize. $J$. Econ. Entomol. 84: 625-632.

Blackman, R. L. and V. F. Eastop (2000) Aphids on the World's Crops: An Identification and Information Guide. 2nd ed. John Wiley \& Sons, New York. 466 pp.

Carter, J. J. (1957) On the biology of the corn leaf aphid. J. Econ. Entomol. 50: 110-112.

Chi, H. (1997) The computer program for the age-stage, two-sex life table analysis. National Chung Hsing University, Taichung, Taiwan (available at: protocol: http:// ftp.nchu.edu.tw/nchu/Ecology/Download/Twosex.zip).

El-Ibrashy, M. T., S. El-Ziady and A. A. Riad (1972) Laboratory studies on the biology of the corn leaf aphid, Rhopalosiphum maidis (Homoptera: Aphididae). Entomol. Exp. Appl. 15: 166-174.

Elliott, N. C., R. W. Kieckhefer and D. D. Walgenbach (1988) Effect of constant and fluctuating temperatures on developmental rates and demographic statistics for the corn leaf aphid (Homoptera: Aphididae). J. Econ. Entomol. 81: 1383-1389.

Everly, R. T. (1960) Loss in corn yield associated with the abundance of the corn leaf aphid, Rhopalosiphum maidis, in Indiana. J. Econ. Entomol. 53: 924-932.

Foott, W. H. and P. R. Timmins (1973) Effects of infestations by the corn leaf aphid, Rhopalosiphum maidis (Homoptera: Aphididae), on field corn in southwestern Ontario. Can. Entomol. 105: 449-458.

Harcourt, D. G. and J. M. Yee (1982) Polynomial algorithm for predicting the duration of insect life stages. Environ. Entomol. 11: 581-584.

Kieckhefer, R. W. and B. H. Kantack (1980) Losses in yield in spring wheat in South Dakota caused by cereal aphids (Homoptera: Aphididae). Environ. Entomol. 73: 582585.

Kieckhefer, R. W. and B. H. Kantack (1986) Yield losses in spring barley caused by cereal aphids. J. Econ. Entomol. 79: 749-752.

Lamb, R. J. (1992) Development rate of Acyrthosiphon pisum (Homoptera: Aphididae) at low temperatures: implications for estimating rate parameters for insects. Environ. Entomol. 21: 10-19.

Meyer, J. S., C. G. Ingersoll, L. L. McDonald and M. S. Boyce (1986) Estimating uncertainty in population growth rates: jackknife vs. bootstrap techniques. Ecology 67: 1156-1166.

Morgan, D., K. F. A. Walters and J. N. Aegerter (2001) Effect of temperature and cultivar on pea aphid, Acyrthosiphon pisum (Hemiptera: Aphididae) life history. Bull. Entomol. Res. 91: 47-52.

Nava-Camberos, U., D. G. Riley and M. K. Harris (2001) Temperature and host plant effects on development, survival, and fecundity of Bemisia argentifolii (Homoptera: Aleyrodidae). Environ. Entomol. 30: 55-63.

Perng, J. J. (2002) Life history traits of Aphis gossypii Glover (Hom., Aphididae) reared on four widely distributed weeds. J. Appl. Entomol. 126: 97-100.

SAS Institute (1989) SAS/STAT User's Guide, version 6, 4th ed. SAS Institute, Cary, NC.

Tang, Y. Q., S. L. Lapointe, L. G. Brown and W. B. Hunter (1999) Effects of host plant and temperature on the biology of Toxoptera citricida (Homoptera: Aphididae). Environ. Entomol. 28: 895-900.

Wang, J. J. and J. H. Tsai (2001) Development, survival and reproduction of black citrus aphid, Toxoptera aurantii (Homoptera: Aphididae). Bull. Entomol. Res. 91: 477487.

Weber, J. D., W. J. A. Volney and J. R. Spence (1999) Intrinsic development rate of spruce budworm (Lepidoptera: Tortricidae) across a gradient of latitude. Environ. Entomol. 28: 224-232.

Weibull, J. H. W. (1993) Bird cherry-oat aphid (Homoptera: Aphididae) performance on annual and perennial temperate-region grasses. Environ. Entomol. 22: 149-153.

Wildermuth, V. L. and E. V. Walter (1932) Biology and control of the corn leaf aphid with special reference to southwestern states. US Dept. Agric. Tech. Bull. 306: 1-21. 